М.М. Дєнєжкін ${ }^{1}$, М.Я. Ткач ${ }^{2}$

${ }^{1}$ Центральний науково-дослідний інститут Збройних Сил України, Київ

${ }^{2}$ Начіональний університет оборони Украйни ім. I. Черняховського, Київ

\title{
ПОГЛЯД НА ОЦІНЮВАННЯ ЗДАТНОСТІ ВІЙСЬКОВИХ ФОРМУВАНЬ ЗБРОЙНИХ СИЛ УКРАЇНИ ВИКОНАТИ ПОСТАВЛЕНІ ЗАВДАННЯ 3 ВИКОРИСТАННЯМ ПРИНЦИПІВ І ПРАВИЛ КРАЇН-ЧЛЕНІВ НАТО
}

У статті на основі результатів аналізу керівних документів, щзо регламентують переведення системи оборонного планування на планування розвитку військових формувань Збройних Сил України (ЗС Украӥни) на основі здатності виконати поставлені завдання, отриманого досвіду визначено, щзо невиріменим залишається питання очінювання здатності військових формувань виконати поставлені завдання. Невирішеність цьього питання не дозволяє якісно формувати вихідні дані для планування розвитку ЗС України з використанням принципів та правил, якими користуються краӥни-члени НАТО.

Визначено, щзо здатність військового формування виконати поставлені завдання для досягнення мети операції вимірюється показниками, які визначаються стандартами (нормативами), щчо характеризують успішність виконання типових завдань (стратегічних, оперативних, тактичних, спеціальних) для типових умов. Військове формування здатне виконати поставлені завдання за умов відповідності наявних значень показників, щуо характеризують успішність виконання поставлених завдань, вимогам до них. Приведення наявних показників, щцо характеризують здатності військового формування виконати завдання, до вимог здійснюється шляхом усунення або мінімізації дефіциту, щуо і складає сутність їх розвитку.

Запропоновано оцінювання здатності військового формування ЗС Украӥни для планування їх розвитку виконати поставлені завдання шляхом комбінації характеристик, щзо використовують ЗС України та країни-члени НАТО. Це дозволяє для планування розвитку ЗС України використовувати кращі практики, норми, принциии і правила країни-членів НАТО.

Ключові слова: спроможність, здатність виконати поставлені завдання, стандарт, норматив, дефіцит, надлишок, розвиток військових формувань.

\section{Вступ}

Актуальність проблеми та її зв'язок із важливими науковими та практичними завданнями. Серед напрямів реалізації воєнної політики України Стратегією воєнної безпеки України визначено впровадження в оборонне планування кращих практик, норм, принципів і правил, якими користуються країни-члени НАТО. Як свідчать результати проведеного оборонного огляду, в ЗС України оцінювання здатності військових формувань виконати поставлені завдання (далі - Здатність) в операціях виявилось найбільш складним, що не дозволяє повною мірою використати планування їх розвиток на основі спроможностей [1]. Необхідністю вирішення цього проблемного питання і визначається актуальність статті.

Аналіз останніх досліджень і публікацій. Чинні керівні документи, що регламентують в ЗС України планування розвитку Здатності [2-7], визначають в основному організаційну сторону виконання цього завдання, але безпосередньо оцінюванню Здатності в них приділяється недостатньо уваги.
Документи країн-членів НАТО, які регламентують визначення Здатності і $є$ в розпорядженні ЗС України, не повною мірою розкривають деталі іiі оцінювання [8-11], оскільки стандарти виконання бойових завдань в операціях (боях) є закритими для вільного доступу і відсутні в Україні.

Документи 3С України, які розкривають визначення характеристик Здатності у відповідних умовах [10-14], є схожими 3 кращими практиками країнчленів НАТО, але спрямовані в основному на визначення ефективності виконання завдань операції та досягнення іiі мети, що робить їх в існуючому вигляді недостатньо придатними для оцінювання Здатності в межах принципів і правил НАТО.

Недостатня адаптація чинних документів ЗС України до кращих практик країн НАТО призвело до неможливості повною мірою вирішити завдання визначення дефіциту або надлишку Здатності, які базуються на результатах оцінювання і покладається в основу побудови та розвитку військових формувань. Це викликає необхідність вирішення завдання оцінювання Здатності військових формувань 
ЗС України на основі принципів і правил країнчленів НАТО.

Формулювання мети статті. Метою статті $\epsilon$ погляд на оцінювання здатності військових формувань ЗС України виконати поставлені завдання в операції для планування їх розвитку з використанням принципів і правил країн-членів НАТО.

\section{Виклад основних положень}

Однією 3 властивостей військового формування є його здатність виконати поставлені завдання в операціях (бойових діях, боях). Серед кращих практик оборонного планування країн-членів НАТО, які запроваджуються в ЗС України, є використання
Здатності для розвитку військових формувань.

В основу розвитку покладається усунення або мінімізація дефіциту (надлишку) Здатності, який викликаний невідповідністю складу та організаційної структури військового формування визначеним вимогам до результативності виконання поставлених завдань. Завдання і заходи усунення або мінімізація дефіциту (надлишку) Здатності здійснюються шляхом кількісно-якісних змін елементів складу військового формування у межах змін базових компонентів (складових) Здатності - вони складають основу програм і планів розвитку $[1 ; 8 ; 13 ; 16]$.

Загальна схема вищезазначених припущень показана на рис. 1.

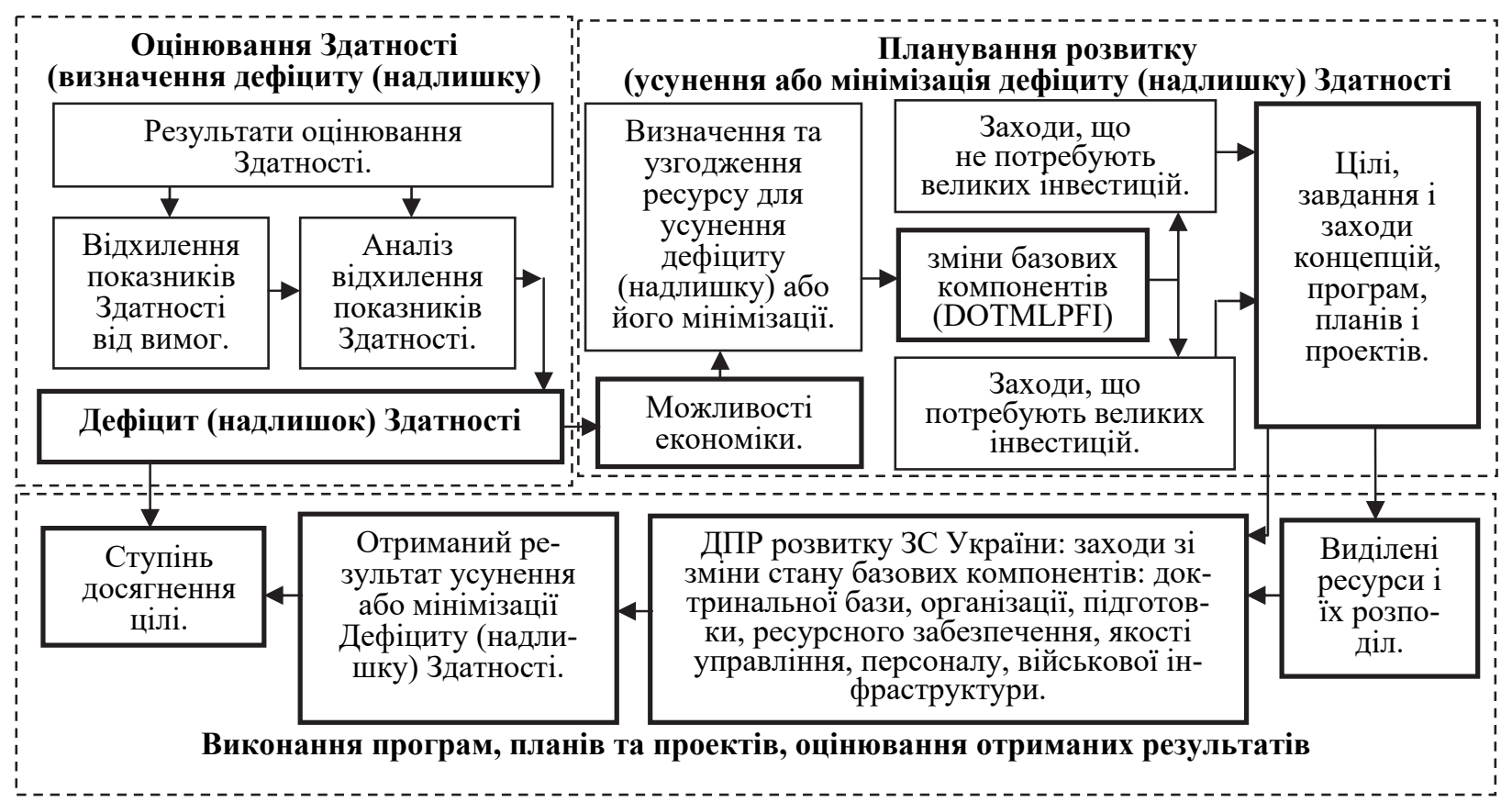

Рис. 1. Схематичне зображення загального процесу визначення заходів зміни базових компонентів (складових) на основі оцінювання дефіциту (надлишку) Здатності для планування розвитку військових формувань

Джерело: розроблено автором.

На рис. 1 показано, що визначення дефіциту (надлишку) Здатності включає такі фази:

визначення різниці кількісних показників результативності виконання визначених завдань;

групування їх за рівнем завдань (стратегічні, оперативні, тактичні) та функціональною ознакою за сферами діяльності;

визначення дефіциту (надлишку) Здатності i аналіз причин їх виникнення.

Результатом виконання концепцій, програм, планів та проектів є отримання нових показників Здатності (сполучення результативності виконання поставлених завдань у визначених умовах), які $\epsilon$ результатом виконання завдань та заходів у межах зміни базових компонентів (складових) спроможностей. Отримані показники здатності під час порів- няння 3 вимогами до них показують ступінь досягнення цілі - усунення або мінімізації дефіциту (надлишку) Здатності.

Вважається, що військове формування здатне виконати (успішно виконати) поставлене завдання ( $3 \partial=P е_{H}^{3 а в д ~} \geq P е 3_{\text {вимог }}^{3 а в д), ~ к о л и ~ н а я в н и и ̆ ~(о т р и м а-~}$ ний) показник результативності ऑii виконання $\left(\mathrm{Pe}_{H}^{3 а в д}\right)$ не менше значень вимог до нього $($ Рез зиялог $)$. Різниця між цими показниками, яка викликана невідповідністю складу та організаційної структури військового формування характеру, масштабу та тривалості воєнних (бойових) дій, $є$ основою для виміру дефіциту або надлишку Здатності [8-9; 12-13]. 
Формально результат досягнення мети в операції ( Рез Опер $)$ військовим формуванням залежить від переліку типових завдань, виконанням яких досягаються цілі операції, стандартів (нормативів) результативності виконання завдань у визначених умовах:

$$
\begin{aligned}
P_{\text {Pe3 }}^{\text {Onep }}= & F\left(N_{C 3}^{i} ; N_{O 3}^{k} ; N_{T 3}^{j} ; N_{C n 3}^{n} ; K_{\text {Hорм }}^{i} ;\right. \\
& \left.K_{\text {Hорм }}^{k} ; K_{\text {Норм }}^{J} ; K_{\text {Hорм }}^{n}\right),
\end{aligned}
$$

де $N_{C 3}^{i}$ - перелік типових стратегічних завдань;

$N_{O 3}^{k}-$ перелік типових оперативних завдань;

$N_{T 3}^{j}$ - перелік типових тактичних завдань;

$N_{C n 3}^{n}$ - перелік типових спеціальних завдань;

$K_{H о р м}^{i}$ - показники стандартів (нормативів) успішності виконання типових стратегічних завдань для визначених умов;

$$
K_{\text {Hорм }}^{k} \text { - показники стандартів (нормативів) }
$$
успішності виконання типових стратегічних завдань для визначених умов;

$$
K_{\text {Норм }}^{J} \text { - показники стандартів (нормативів) }
$$

успішності виконання типових оперативних завдань для визначених умов;

$$
K_{\text {Норм }}^{n} \text { - показники стандартів (нормативів) }
$$

успішності виконання типових тактичних завдань для визначених умов.

В арміях різних країн по-різному визначають Здатність, але практично всі для визначення даних для розвитку військових формувань використовують механізм усунення або мінімізації дефіциту (надлишку) Здатності у визначених умовах. Це свідчить про те, що визначення дефіциту або надлишку є ключовим оцінювання Здатності в ході підготовки даних для планування розвитку військових формувань (рис. 2).

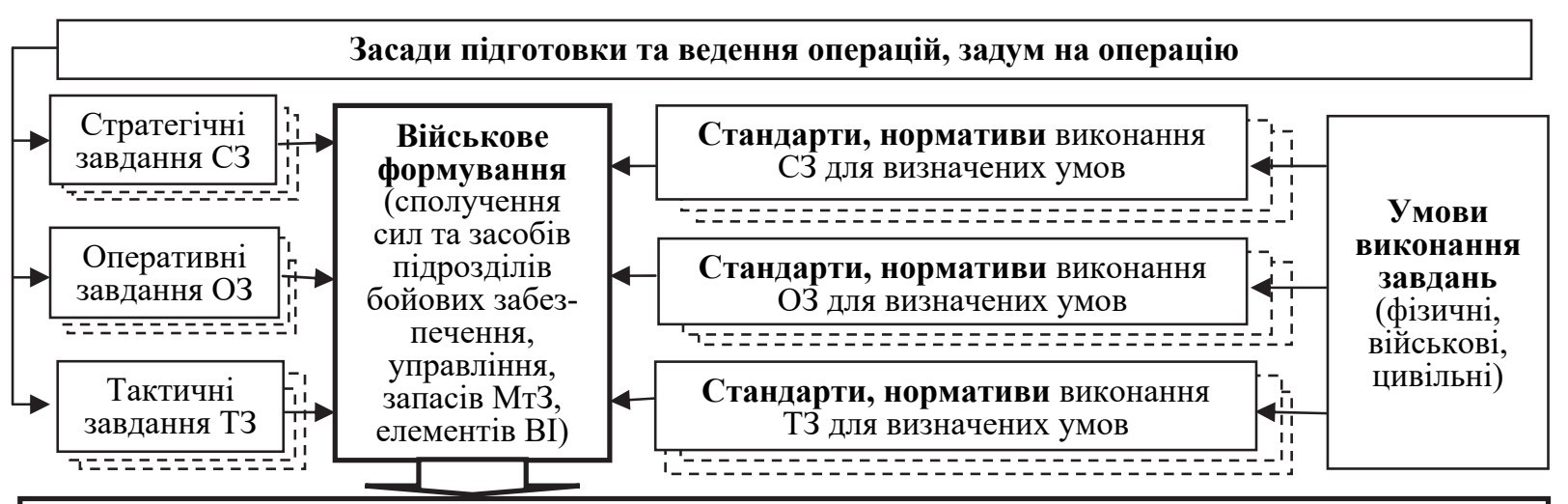

Характеристика здатності виконати поставлені завдання:

Характеристика здатності виконати поставлені завдання:
$-\quad$ показники результативності виконання бойових завдань (стратегічних, оперативних, тактичних),
які розраховані для типових умов (включають просторові, часові, ударні, вогневі, спеціальні показ-
ники і т. ін.);
- показники, які кількісно і якісно характеризують можливості військового формування 3 вико-
нання типових завдань в операції (бою) для визначених умов.

Рис. 2. Схематичне зображення складових, які обумовлюють результат виконання типових завдань військовим формуванням в операціях (боях) у визначених умовах їх виконання Джерело: [12-13].

Військове формування $є$ сукупністю бойових формувань, формувань забезпечення (оперативного (бойового), тилового, технічного та медичного), запасів витратних Мт3, елементів військової інфраструктури. Здатність військового формування виконати перелік типових завдань, який визначається задумом на операцію (бій), характеризується відповідними показниками результативності їх виконання. Вони розраховуються для конкретних умов (рівнівна, гірська, болотиста місцевість, ліс, місто, пустеля і т. ін.) і відрізняються від тих, що розраховані для типових умов [8-9].

У країнах-членах НАТО, на принципи і стандарти яких переходять ЗС України, здатність військових формувань виконати перелік типових завдань в операціях включає такі показники: готовність військ (сил); розвідка; розгортання та мобільність; ефектив- ність застосування військ (сил); управління та зв'язок (інформаційні системи); всебічне забезпечення; живучість та захист військ (сил) [8-10; 14]. Ці показники мають конкретні чисельні величини для типових умов. У визначених вимогами до Здатності конкретних умовах ці показники змінюють кількісні величини на величину відхилення реальних від типових умов.

Дефіцит (надлишок) Здатності визначається на основі невідповідності кількісних величин вимог до показників результативності виконання переліку визначених завдань наявним (отриманим) показникам, які за функціональною ознакою розподіляються за сферами діяльності (управління, застосування, забезпечення, живучість, мобільність, готовність, інформованість і т. ін.) (табл. 1) 
Групи показників, що характеризують результативність виконання типових завдань в операції [14]

\begin{tabular}{|c|c|c|c|}
\hline $\begin{array}{l}\text { № } \\
\text { 3/ח }\end{array}$ & $\begin{array}{c}\text { Групи показників } \\
\text { результативності } \\
\text { виконання типових } \\
\text { завдань } \\
\end{array}$ & $\begin{array}{c}\text { Загальний опис виконання типових } \\
\text { завдань в операції }\end{array}$ & Одиниця виміру \\
\hline 1 & 2 & 3 & 4 \\
\hline 1 & Готовність & $\begin{array}{l}\text { Здатність щодо створення та утри- } \\
\text { мання необхідної (достатньої) кілько- } \\
\text { сті військ (сил) для своєчасного і ефе- } \\
\text { ктивного реагування на будь-які за- } \\
\text { грози (виклики), що зумовлені зміна- } \\
\text { ми в обстановці, із забезпеченням } \\
\text { можливості нарощування складу } \\
\text { військ (сил) з використанням встанов- } \\
\text { леної системи ступенів бойової готов- } \\
\text { ності та проведення ротацій військ } \\
\text { (сил), що задіяні в поточних операціях } \\
\text { (діях). }\end{array}$ & $\begin{array}{l}\text { Час готовності як сума часу на } \\
\text { проведення запланованих заходів, } \\
\text { які доводять здатність досягнення } \\
\text { результату (ефекту) до максималь- } \\
\text { ного значення. } \\
\text { Обсяги ресурсів для виконання } \\
\text { заходів. }\end{array}$ \\
\hline 2 & Розвідка & $\begin{array}{l}\text { Здатність щодо збору, обробки та } \\
\text { своєчасного доведення достовірної } \\
\text { інформації для забезпечення ефектив- } \\
\text { ності ії використання для прогнозу } \\
\text { розвитку загальної ситуації та окре- } \\
\text { мих подій, зумовлених виникненням } \\
\text { загроз (викликів) національній безпеці } \\
\text { держави, діями противника або нас- } \\
\text { лідками природних і техногенних } \\
\text { аварій та катастроф. }\end{array}$ & $\begin{array}{l}\text { Імовірність викриття намірів } \\
\text { противника. } \\
\text { Ступінь викриття об'єктів про- } \\
\text { тивника для ураження. } \\
\text { Час на виконання завдань розві- } \\
\text { дки. }\end{array}$ \\
\hline 3 & $\begin{array}{c}\text { Розгортання } \\
\text { та мобільність }\end{array}$ & $\begin{array}{l}\text { Здатність щодо своєчасного зосере- } \\
\text { дження військ (сил) та засобів у ви- } \\
\text { значеному місті (розгортання) та здій- } \\
\text { снення ними швидких переміщень під } \\
\text { час виконання завдань в районі дій } \\
\text { (мобільність). }\end{array}$ & $\begin{array}{l}\text { 1. Час на розгортання сил та за- } \\
\text { собів. } \\
\text { 2. Швидкість на полі бою, шосе, } \\
\text { грунтовими шляхами. Час на роз- } \\
\text { гортання у бойовий порядок. } \\
\text { 3. Здатність до перекидання ін- } \\
\text { шими засобами (повітряним, річ- } \\
\text { ковим та морським транспортом, } \\
\text { засобами переправи). }\end{array}$ \\
\hline 4 & $\begin{array}{l}\text { Застосування військ } \\
\text { (сил) }\end{array}$ & $\begin{array}{l}\text { Здатність ефективно застосовувати } \\
\text { війська (сили), озброєння та військову } \\
\text { техніку у будь-яких умовах обстанов- } \\
\text { ки. }\end{array}$ & $\begin{array}{l}\text { 1.Просторові спроможності (ши- } \\
\text { рина та глибина району оброни; } \\
\text { глибина виконання завдань. } \\
\text { 2.Вогневі спроможності: кіль- } \\
\text { кість одночасно уражених об'єктів } \\
\text { противника; ступінь вогневого } \\
\text { ураження. } \\
\text { 3.Ударні спроможності: ширина } \\
\text { ділянки прориву оборони против- } \\
\text { ника; здатність відбити напад; } \\
\text { спроможність до нанесення контр- } \\
\text { атак (контрударів). }\end{array}$ \\
\hline 5 & $\begin{array}{l}\text { Управління та зв'язок } \\
\text { (інформаційні } \\
\text { системи) }\end{array}$ & $\begin{array}{l}\text { Здатність організовувати та ефекти- } \\
\text { вно здійснювати управління війська- } \\
\text { ми (силами), зброєю під час підготов- } \\
\text { ки та у ході виконання ними визначе- } \\
\text { них завдань }\end{array}$ & $\begin{array}{l}\text { Тривалість циклу управління. } \\
\text { Імовірність упередження проти- } \\
\text { вника в управлінні. } \\
\text { Час реакції на зміну обстановки. }\end{array}$ \\
\hline 6 & $\begin{array}{c}\text { Всебічне } \\
\text { забезпечення }\end{array}$ & $\begin{array}{l}\text { Здатність здійснювати своєчасне } \\
\text { забезпечення ресурсами операцій, } \\
\text { бойових та інших дій військ (сил) } \\
\text { впродовж всього часу їх ведення, для } \\
\text { забезпечення досягнення мети їх за- } \\
\text { стосування. }\end{array}$ & $\begin{array}{l}\text { Ступінь оснащеності, укомплек- } \\
\text { тованості - співвідношення реаль- } \\
\text { ного показника до вимог нормати- } \\
\text { ву (стандарту). }\end{array}$ \\
\hline
\end{tabular}




\begin{tabular}{|c|c|c|c|}
\hline & & & Закінчення табл. \\
\hline 1 & 2 & 3 & 4 \\
\hline 7 & $\begin{array}{c}\text { Захист та живучість } \\
\text { військ (сил) }\end{array}$ & $\begin{array}{l}\text { Здатність забезпечувати мінімізацію } \\
\text { наслідків від будь-яких дій противни- } \\
\text { ка (включаючи застосування зброї } \\
\text { масового ураження та негативного } \\
\text { впливу середовища, у т.ч. - від нас- } \\
\text { лідків природних і техногенних аварій } \\
\text { та катастроф) }\end{array}$ & $\begin{array}{l}\text { Втрати від засобів ураження } \\
\text { противника з повітря, моря, суші, } \\
\text { ближнього космосу, в інформацій- } \\
\text { ній сфері. } \\
\text { Час збереження боєздатності під } \\
\text { час протидії противника. } \\
\text { Оснащеність ОВТ, Мт3. } \\
\text { Укомплектованість ОС. } \\
\text { Навченість. }\end{array}$ \\
\hline
\end{tabular}

Джерело: [14].

Як видно з табл. 1, результативність виконання завдань в операції визначається групами показників результативності виконання типових завдань та частковими (мають просторовий, часовий, ударний, маневровий і інші виміри). Невідповідність чисельних значень поточних показників вимогам до них використовують для аналізу причин виникнення дефіциту або надлишку Здатності. Результати цього аналізу у наступному використовуються для визначення необхідних ресурсів, для приведення отриманого показника результативності до показників вимог. Слід мати на увазі, що зміст показників надано у загальному вигляді, а стандарти (нормативи) визначають їх кількісні величини, виходячи із рівня завдань (стратегічне, оперативне, тактичне або спеціальне), умов їх виконання, а також місця в бойовому порядку (оперативній побудові) військ (сил).

Стандарти виконання завдань в НАТО - норми (зразки) виконання завдань. Вони $є$ доповненням до переліку завдань, метою яких $є$ визначення критеріїв та часткових показників їх виконання у військовій сфері діяльності. Стандарти дозволяють штабам визначати та оцінювати склад військ (сил), показни- ки, які описують параметри виконання завдань [15].

У ЗС України Здатність військового формування характеризується показниками їх “бойових та спеціальних можливостей”, які розраховані для типових умов. Військове формування здатне виконати поставлені завдання, якщо значення показників ї бойових та спеціальних можливостей відповідають вимогам до них для заданих умов [3-6; 12-13].

Бойові та спеціальні можливості військового формування вимірюються імовірністю або надійністю виконання завдання, що поставлено, математичним очікуванням втрат, що завдаються противнику та противником, а також оперативно-тактичними параметрами операції та нормативами. Характеристики бойових можливостей $є$ основою для розрахунків нормативів 3 виконання типових завдань, які включають просторові, часові, ударні, вогневі, маневрові та інші показники. Вони кількісно і якісно характеризують потенціальну здатність військ (сил) 3 виконання завдань в операції (бою) [10; 15-16]. Оцінювання Здатності в ЗС України є ідентичним 3 країнами-членами НАТО (рис. 3).

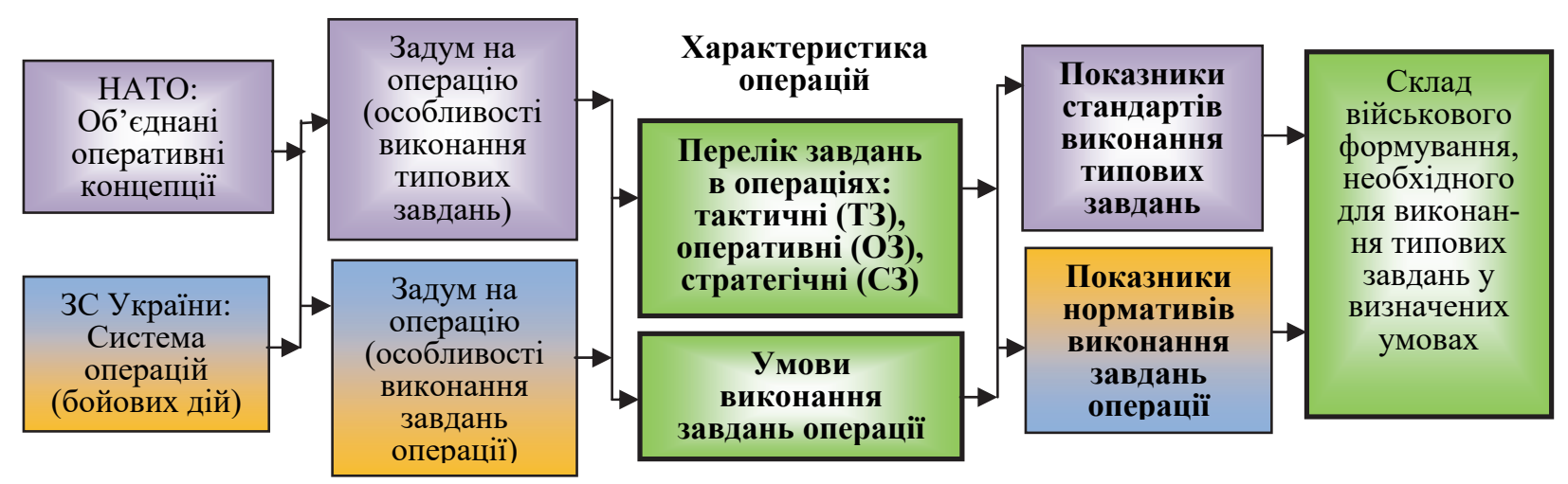

Рис. 3. Схематичне зображення визначення складу військового формування в країнах-членах НАТО та в ЗС України на основі оцінювання здатності виконати типові завдання в операції Джерело: [13; 16].

Характеристики Здатності в практиці НАТО є більш детальними та систематизованими, що полегшує здійснення оцінювання. ЗС України використовують практично всі ті ж характеристики, але вони розглядаються окремо і не систематизовані, як в НАТО [14]. Це свідчить про те, що доцільно використовувати характеристики Здатності, якими користуються в ЗС України. При цьому групувати і сис- 
тематизувати ці характеристики, як це роблять в країнах-членах НАТО [13].

Визначення дефіциту (надлишку) Здатності, аналіз причин виникнення, а також формування пропозицій щодо його усунення або мінімізації здійснюється, як правило, із використанням методу експертних оцінок. Сполучення виміру та експертного аналізу забезпечує отримання об'єктивного та точного оцінювання показників результативності виконання поставлених завдань та визначення тих 3 них, які наявним складом виконати не можна, а також кваліфікованого (експертного) визначення шляхів, завдань та заходів щодо усунення дефіциту (надлишку) Здатності або його мінімізації [13].

В ході проведення оборонного огляду в 3С України дефіцит (надлишок) Здатності визначався методом експертних оцінок. Це свідчить про те, що оцінений дефіцит (надлишок) Здатності на першій фазі не мав чітко визначених кількісних значень відхилення показників результативності виконання поставлених завдань, що не дозволило окреслити завдання, які існуючим складом не можна виконати, а також ускладнило подальший розподіл дефіциту (надлишку) за сферами діяльності військових формувань.

Розподіл дефіциту (надлишку) Здатності за сферами діяльності дозволяє чітко визначити, де у військовому формуванні, яких (бойових, спеціальних) спроможностей не вистачає ( $\epsilon$ надлишок) в управлінні, застосуванні бойових формувань, формувань забезпечення (бойового, тилового, технічного, медичного). Це у подальшому дозволяє визначити, які конкретні формування, які їх елементи (складові) потребують кількісно-якісних змін [14].

Використання відомого як надійного методу експертних оцінок для визначення шляхів усунення або мінімізації дефіциту (надлишку) Здатності обумовлено тим, що теоретично комбінацій засобів в організаційній структурі військових формувань може бути безліч, але наявну при цьому “непродуктивну" частину варіантів, яка не може бути взята до виконання, можна обійти за допомогою досвідчених експертів.

Визначення елементів (складових) військового формування, які потребують кількісних та якісних змін, практично визначають завдання щодо постачання OBT, витратних засобів Мт3, елементів військової інфраструктури, особового складу для того, щоб відповідати вимогам до Здатності. Якісні зміни визначають створення нових або модернізацію зразків ОВТ шляхом підвищення їх ТТХ. Кількісні зміни у складі військових формувань, подальшу їх підготовку до виконання завдань у визначених умовах визначає розвиток організаційної структури або проведення організаційних заходів.

Підсумовуючи вищезазначене, для оцінювання здатності військових формувань 3С України виконати поставлені завдання доцільно:

1. Для визначення переліку можливих операцій використовувати систему операцій, а також послідовність їх проведення (основні положення задуму на ведення воєнних дій).

2. Використовувати показники здатності виконати перелік завдань в операції, якими досягається мета відповідної операції.

3. Показники, що характеризують результативність досягнення мети (цілей) операції, виконання завдань в операції групувати за принципом, який використовують країни-члени НАТО.

4. Для характеристики результативності виконання переліку завдань в умовах відсутності чіткого визначення в стандартах НАТО, використовувати показники результативності виконання визначених завдань військовим формуванням в операції, які встановлені нормативами, що використовуються в ЗС України.

5. Дефіцит (надлишок) здатності виконати перелік завдань в операції визначати за різницею між реальним значенням показника та вимогами результативності виконання переліку завдань до нього, що визначені нормативами за реальних умов виконання завдань.

Це дозволить визначати дефіцит або надлишок Здатності військових формувань, який у подальшому дасть змогу розраховувати обсяги ресурсів та заходи розвитку військових формувань, повною мірою використовувати кращі практики НАТО в ЗС України.

\section{Висновки}

Запропонований підхід щодо оцінювання здатності військових формувань ЗС України виконати поставлені завдання в операції для планування їх розвитку з використанням принципів і правил країнчленів НАТО дозволить адаптувати чинні документи 3С України до використання кращих практик країн НАТО, поступово перейти до планування розвитку військових формувань на основі оцінювання Здатності.

Перспективою подальших досліджень може бути використання результатів оцінювання Здатності для:

уточнення характеристик Здатності, їх одиниць виміру;

визначення дефіциту (надлишку) Здатності на основі співвідношення вимог до неї та кількісних величин наявних характеристик;

визначення завдань і заходів до плануючих документів, потреби в ресурсах та кількісно-якісних змін базових компонентів спроможностей для усунення або мінімізацію дефіциту (надлишку) Здатності. 


\section{Список літератури}

1. Дєнєжкін М. М., Гаврилюк Н. А. Проблемні питання переходу до планування розвитку спроможностей військових формувань Збройних Сил України та шляхи їх вирішення. Збірник наукових пращь Центрального науково-дослідного інституту Збройних Сил України. 2020. № 4(95). С. 25-35.

2. Про державні цільові програми : Закон України від 18.03.2004 р. № 1621-IV. Відомості Верховної Ради Украӥни. 2004. № 25. С. 352.

3. Рекомендації з оборонного планування на основі спроможностей в Міністерстві оборони України та Збройних Силах України : Затверджені Міністром оборони України 12.06.2017 р. Київ : МО України, 2017. 52 с.

4. Рекомендації з порядку організації проведення оцінювання спроможностей у Збройних Силах України : Затверджені Міністром оборони України 07.12.2017 р. Київ : МО України. 27 с.

5. ВСТ 01.040 .003 - 2014 (01). Оборонне планування. Державна програма розвитку Збройних Сил України. [Чинний від 2014-12-16]. Вид. офіц. Київ : Міноборони України, 2014. 18. с. (Порядок розроблення).

6. Методичні рекомендації з організації та проведення оборонного огляду : Затверджені Міністром оборони України 07.06.2019 р. Київ : МО України. 50 с.

7. Інструкція з організації підготовки та проведення перевірок у Збройних Силах України : Наказ Генерального штабу Збройних Сил України. 2020 р. № 6.

8. NATO Research and Technology Board: Panel On Studies, Analysis and Simulation (SAS), Handbook in Long Term Defense Planning, 2001

9. Defense Capability Development Handbook Australia 2014. URL : Capability Development@defence.gov.au.

10. Capabilities-Based Assessment (CDA) User`s Guide Version 3. Force Structure, Researches, and Assessment Directorate (JCS J08). March 2009. P. 97.

11. Operational Research Tools supporting the Force Development Process for the Canadian Forces. Ms. Debbie Blakeney "Defence Research and Development Canada - Centre for Operational Research and Analysis (DRDC-CORA) UMSSOFT" Sofia, Bulgaria, 26-29 June 2007.

12. Дєнєжкін М. М., Дідіченко В. П., Савостьянов А. Ф., Соболєв О.М., Сюсаренко М. О. Звіт НДР (шифр «Напруга»). 2003 р. Київ : ЦНДІ ЗС України. С. 186.

13. Дєнєжкін М. М., Дідіченко В. П., Середюк С. А. Основні положення оцінювання спроможностей військових формувань під час планування їх розвитку. Інформаційно-аналітичні матеріали. Київ : ЦНДІ ЗС України, 2020. С. 123.

14. Universal joint task list (ujtl). Joint Staff Washington, d.c. 20318 chairman of the joint chiefs of staff manual j-7 CJCSM 3500.04d distribution: $a, b, c, j$, s 1 August 2005. P. 867.

15. Советская Военная Энциклопедия: В 8 томах / Пред. Гл. ред. комиссии М. А. Моисеев. - 2-е изд. Т. 1: «А»Бюлов. - М.: Воениздат, 1990. 543 с.

16. Дєнєжкін М. М., Дідіченко В. П., Павловський О. В., Середюк С. А. Звіт НДР (шифр «Розвиток-ОП») (заключний). 2019 р. Київ : ЦНДІ ЗС України. С. 86.

\section{Відомості про авторів:}

\section{Дєнєжкін Микола Миколайович}

доктор військових наук старший науковий співробітник провідний науковий співробітник

Центрального науково-дослідного інституту

Збройних Сил України,

Київ, Україна

https://orcid.org/0000-0003-0918-0880

\section{Ткач Микола Якович}

кандидат технічних наук

начальник кафедри

Національного університету оборони України

ім. І. Черняховського,

Київ, Україна

https://orcid.org/0000-0002-8832-1268

\section{Information about the authors:}

\section{Mykola Dieniezhkin}

Doctor of Military Sciences Senior Research

Lead Research

of Central Scientific-Research Institute

of Armed Forces of Ukraine,

Kyiv, Ukraine

https://orcid.org/0000-0003-0918-0880

\author{
Mykola Tkach \\ Candidate of Technical Sciences \\ Head of Department \\ of National University of Defense of Ukraine \\ named after Ivan Cherniakhovsky, \\ Kyiv, Ukraine \\ https://orcid.org/0000-0002-8832-1268
}




\section{ВЗГЛЯД НА ОЦЕНКУ СПОСОБНОСТИ ВОЙСКОВОГО ФОРМИРОВАНИЯ ВООРУЖЕННЫХ СИЛ УКРАИНЫ ВЫПОЛНИТЬ ПОСТАВЛЕННЫЕ ЗАДАЧИ С ИСПОЛЬЗОВАНИЕМ ПРИНЦИПОВ И ПРАВИЛ СТРАН-ЧЛЕНОВ НАТО}

\section{Н.Н. Денежкин, Н.Я. Ткач}

В статье на основе анализа руководящих документов, которые регламентируют перевод системы оборонного планирования на планирование развития формирований Вооруженных Сил Украины (ВС Украины) определено, что не решенным вопросом остается оценка способности войсковых формирований выполнить поставленные задачи, что не позволяет качественно формировать данные с использованием принципов и правил стран-членов НАТО. Определено, что способность войскового формирования выполнить поставленные задачи для достижения цели операции оценивается показателями, которые определяются стандартами (нормативами) и характеризуют успешность выполнения типовых задач (стратегических, оперативных, тактических, специальных). Войсковое формирование способно выполнить поставленные задачи при условии соответствия полученных значений показателей, что характеризуют успешность выполнения поставленных задач, требованиям к ним. Предложено при оиенивании способности войскового формирования ВС Украины для планирования его развития использовать оценку способности выполнить поставленные задачи путем комбиначии характеристик, которые используют ВС Украины та страны-члены НАТО. Это позволяет для планирования развития ВС Украины использовать лучшие практики, нормы, принципы и правила стран-членов HATO.

Ключевые слова: способность выполнить поставленные задачи, стандарты, нормативы, дефицит, избыток, развитие войскового формирования.

\section{A LOOK AT THE ASSESSMENT OF THE ABILITY OF MILITARY FORMATIONS OF THE ARMED FORCES OF UKRAINE TO PERFORM THE OBJECTIVES USING THE PRINCIPLES AND RULES OF COUNTRIES-MEMBERS OF NATO}

M. Dieniezhkin, M. Tkach

Based on the results of the analysis of guiding documents regulating the transfer of the defense planning system to the planning of the development of military formations of the Armed Forces of Ukraine (AF of Ukraine) based on the ability to perform tasks, the experience shows that the issue of assessing the ability of military formations to perform tasks remains unresolved. The unresolved issue does not allow to qualitatively form the initial data for planning the development of the Armed Forces of Ukraine using the principles and rules used by NATO member countries.

It is determined that the ability of a military formation to perform tasks to achieve the purpose of the operation is measured by indicators that are determined by standards (norms) that characterize the success of standard tasks (strategic, operational, tactical, special) for typical conditions. The military formation is able to perform the tasks under conditions of compliance with the available values of indicators that characterize the success of the tasks, the requirements for them. Bringing the existing indicators that characterize the ability of the military formation to perform the tasks to the requirements is carried out by eliminating or minimizing the deficit, which is the essence of their development.

It is proposed to assess the ability of the military formation of the Armed Forces of Ukraine to plan their development to perform the tasks by combining the characteristics used by the Armed Forces of Ukraine and NATO member countries. This allows the best practices, norms, principles and rules of NATO member countries to be used for planning the development of the Armed Forces of Ukraine.

Keywords: ability, ability to fulfill the set tasks, standard, norm, deficit, surplus, development of military formations. 